\title{
Identifikasi Pemahaman Konsep Siswa dalam Muatan IPS Kelas V SDN Mlajah 1 Bangkalan
}

\author{
Anni Farika ${ }^{1)^{*}}$, Agung Setyawan $^{1)}$, Tyasmiarni Citrawati $^{1)}$ \\ ${ }^{1)}$ Universitas Trunojoyo Madura \\ *170611100032@student.trunojoyo.ac.id
}

Artikel Info

Tanggal Publikasi

2020-06-30

Kata Kunci

Pemahaman Konsep,

IPS,

Siswa Kelas V.
Abstrak

Penelitian ini adalah studi awal dalam Identifikasi permasalahan yang dihadapi kelas V SDN Mlajah 1 Bangkalan dalam muatan IPS. Identifikasi permasalah dalam permbelajaran IPS dilaksanakan agar dapat ditemukan sebuah solusi dalam upaya peningkatan pemahaman konsep siswa dalam pembelajaran IPS. Instrument pengumpulan data dilakukan dengan menggunakan instrument tes, wawancara dan observasi yang Jumlah siswa kelas ini sebanyak 25 siswa yang terdiri dari 10 siswa laki-laki dan 15 siswa perempuan. Hasil dari permasalahan penelitian ini menunjukkan bahwa tingkat pemahaman belajar siswa di SDN Mlajah 1 tergolong masih rendah dan hasil penyebaran tes presentase pemahaman konsep belajar kelas $\mathrm{V}$ menunjukkan rata-rata pemahaman konsep siswa kelas $\mathrm{V}$ tersebut sekitar 34,375 \% Dapat mengenal letak dan luas Indonesia melalui. 22,50\% Dapat menyebutkan letak. 3,72\% Dapat menggambar sebuah peta. 19,375\% Siswa dapat menentukam garis-garis yang terdapat dalam letak geografis dan 5,625\% Siswa dapat menentukan jarak pada peta.

\section{Pendahuluan}

Susanto (2013: 137) menjelaskan bahwa Ilmu pengetahuan sosial, yang sering disingkat dengan IPS merupakan ilmu pengetahuan yang mengkaji berbagai disiplin ilmu sosial dan humaniora serta kegiatan dasar manusia yang dikemas secara ilmiah dalam rangka memberi pandangan dan pemahaman yang luas kepada siswa, khususnya jenjang sekolah dasar dan menegah.

Oemar Hamalik (1992, hlm. 40) mengungkapakan bahwa tujuan pendidikan IPS berorientasi pada perilaku siswa, yaitu: 1) pengetahuan dan pemahaman, 2) sikap hidup belajar, 3) nilai-nilai sosial dan sikap, 4) keterampilan. Tujuan pendidikan IPS tersebut salah satunya adalah pengetahuan dan pemahaman. Akan tetapi jika kita melihat fakta dilapangan, pemerolehan pemahaman peserta didik dalam mata muatan IPS ini masih dikatakan rendah sehingga menyebabkan peserta didik tidak memiliki pemahaman konsep yang kuat mengenai materi-materi IPS.

Susanto (2014, hlm. 3) menjelaskan bahwa kelemahan yang mengakibatkan pemahaman konsep siswa rendah termasuk diantaranya yaitu seoran guru kurang mengamati peserta didik dalam proses pembelajaran, tetapi guru lebih cenderung menggunakan ceramah yang hanya menuntut siswa pada ingatan dan hafalan kejadian-kejadian serta nama-nama tokoh, tanpa membangun pandangan berpikir dalam penyelesaian persoalan yang memungkinkan peserta didik dapat belajar lebih aktif. Pada dewasa ini guru terkadang masih menggunakan metode mengajar ceramah terutama pada mata pelajaran yang banyak teori juga konsep-konsepnya seperti mata pelajaran IPS, tanpa guru sadari metode ceramah tersebut membuat siswa mengantuk ketika mengkuti pembelajaran IPS. Pembelajaran IPS bukannya menyenangkan, malah dianggap sebagai pembelajaran yang membuat jenuh. Selain hal tersebut, motivasi siswa pun menjadi rendah karena kurangnya inovasi dalam pembelajaran IPS di dalam kelas. 
Motivasi belajar yang rendah akan menyebabkan kurangnya perhatian siswa terhadap mata pelajaran tertentu khusunya IPS dan tentunya akan mempengaruhi keberhasilan pemahaman konsep.

Penelitian ini merupakan langkah awal mengindentifikasi pemahaman belajar siswa dalam pembelajaran IPS kelas V SD Negeri Mlajah 1 Bangkalan dan supaya untuk menangani permasalahan yang dihadapi oleh peserta didik dan guru. Informasi yang diperoleh penting untuk mengetahui halhal apa saja yang menyebabkan rendahnya pemahaman belajar siswa dalam muatan IPS, sehingga dapat menentukan strategi pembelajaran yang tepat untuk mencegah rendahnya pengetahuan tentang pemahaman konsep belajar siswa dapat terulang kembali.

Guru harusnya lebih berinovasi lagi dengan menerapkan berbagai macam model pembelajaran dalam mata pelajaran IPS agar proses pembelajaran dapat lebih memudahkan dan bermakna. Mata pelajaran IPS merupakan salah satu mata pelajaran penting yang harus dipahami dan dikuasai oleh siswa-siswa khusunya siswa disekolah dasar, karena dalam mata pelajaran ini siswa akan memperoleh ilmu-ilmu mengenai keterampilan sosial yang dapat digunakan dan diterapkan oleh mereka di dalam kehidupan sehari-hari.

Menurut Anderson (2014, hlm.100) Indikator pemhaman konsep terdiri dari Menafsirkan atau menerangkan, menjelaskan, mencontohkan, merangkum dan menyimpulkan. Sehingga pada penelitian kali ini peneliti akan mengutamakan pada peningkatan pemahaman konsep dalam kemampuan menafsirkan, menjelaskan, mencontohkan dan merangkum.

\section{Metode Penelitian}

Metode yang digunakan dalam penelitian ini adalah metode Survey dengan menggunakan tes dan wawancara. Jumlah siswa kelas ini sebanyak 25 siswa yang terdiri dari 10 laki-laki dan 15 perempuan. Responden sebanyak 25 siswa dan 1 guru kelas V di SDN Mlajah 1 Bangkalan. Informasi yang diperoleh dari pengumpulan tes yang dilakukan mulai tanggal 25 Februari 2020. Tes berisi pernyataan yang menggali informasi awal tentang permasalahan siswa. Data yang diperoleh dari hasil tes siswa diperkuat dengan melakukan wawancara kepada guru kelas $\mathrm{V}$. Wawancara berisi sejumlah pertanyaan kepada guru kelas tentang permasalahan yang dialami siswa dan bentuk tindakan yang dilakukan.

\section{Hasil dan Pembahasan}

\section{Hasil}

Berdasarkan permasalahan yang ada dari studi pendahuluan dengan menggunakan tes, dan wawancara di dapatkan hasil bahwa beberapa masalah yang ditemukan dalam pemberian tes yang dilakukan pada siswa kelas V. Hasil dari pemberian tes yaitu kebanyakan siswa kurang memahami mengenai materi tentang Letak Geografis Penyebab kurang pahamnya siswa terhadap materi dikarenakan pada mata pelajaran Ilmu Pengetahuan Sosial (IPS) siswa sulit untuk menghafal dan memahami pembelajaran. Akibat dari tidak menghafal dan memahami pembelajaran siswa menjadi sulit mengerti penjelasan yang dijelaskan oleh guru. Tindakan yang dilakukan oleh guru saat siswa kurang paham terhadap materi, guru memberikan kesempatan kepada siswa untuk mengajukan pertanyaan jika ada yang kurang dimengerti. Setelah itu guru memberikan penjelasan ulang kepada siswa sehingga siswa menjadi lebih paham terhadap materi.

Berdasarkan hasil wawancara kepada guru kelas $\mathrm{V}$ yang dilakukan di SD Negeri Mlajah 1 Bangkalan. Didapatkan hasil bahwa Materi yang sulit dimengerti siswa kelas V yaitu materi tentang Letak Geografis dalam pembelajaran Ilmu Pengetahuan Sosial (IPS) siswa sulit untuk menghafal dan memahami pembelajaran,kurang memahami materi tentang letak geografis kurangnya dorongan dari orang tua siswa, kurangnya latihan dirumah, dan salah satu metode pembelajaran yang digunakan guru saat mengajar dikelas yaitu metode diskusi, ceramah dan disertai mencatat, siswa mempunyai catatan 
yang dapat digunakan untuk belajar sendiri, dan untuk evaluasi yang dilakukan yaitu guru akan memberi waktu untuk siswa bias bertanya, menjawab pertanyaan yang dilontarkan oleh guru dan guru akan memberikan nilai khusus bagi siswa yang aktif, tiudak ada ketergantungan antar siswa.. Sehingga cara pembelajaran yang dilakukan oleh guru tersebut mengakibatkan kekurang sadaran siswa untuk memahami materi.

Tabel 1. Hasil Presentase Indikator Pemahaman Konsep Belajar Siswa

\begin{tabular}{|c|c|c|}
\hline Indikator & Deskripsi & Presentase \\
\hline \multirow[t]{3}{*}{$\begin{array}{l}\text { Kemampuan menyatakan ulang } \\
\text { sebuah pemahaman konsep }\end{array}$} & $\begin{array}{l}\text { 1. Dapat mengenal letak dan luas Indonesia } \\
\text { melalui peta. }\end{array}$ & $34,375 \%$ \\
\hline & 2. Dapat menyebutkan letak geografis & $22,50 \%$ \\
\hline & 3. Dapat menggambar sebuah peta & $3,75 \%$ \\
\hline $\begin{array}{l}\text { Kemampuan menyajikan konsep } \\
\text { dalam bentuk represntasi letak }\end{array}$ & $\begin{array}{l}\text { 1. Siswa dapat menentukam garis-garis yang } \\
\text { terdapat dalam letak geografis }\end{array}$ & $19,375 \%$ \\
\hline geografis & 2. Siswa dapat menentukan jarak pada peta & $5,625 \%$ \\
\hline
\end{tabular}

Berdasarkan hasil penyebaran tes presentase pemahaman konsep belajar kelas $\mathrm{V}$ menunjukkan rata-rata pemahaman konsep siswa kelas V tersebut sekitar 34,375 \% Dapat mengenal letak dan luas Indonesia melalui. 22,50\% Dapat menyebutkan letak. 3,72\% Dapat menggambar sebuah peta. 19,375\% Siswa dapat menentukam garis-garis yang terdapat dalam letak geografis dan 5,625\% Siswa dapat menentukan jarak pada peta. Rendahnya pemahaman konsep belajar siswa bias mempengaruhi semangat dalam mengikuti pembelajaran. Pemahaman siswa terhadap suatu mata pelajaran atau materi akan mendorong siswa untuk berusaha melakukan yang terbaik demi memahami mata pelajaran atau materi tersebut. Apabila siswa tidak memahami terhadap mata pelajaran yang ada maka siswa tidak akan sungguh-sungguh dalam mendengarkan dan memperhatikan penjelasan guru. Untuk meningkatkan pemahaman peserta didik terhadap suatu pembelajaran salah satu cara yaitu dengan melakukan pembelajaran yang menyenangkan.

\section{Pembahasan}

Berdasarkan hasil yang diperoleh menunjukkan bahwa materi yang sulit dipahami siswa yaitu mengenai materi letak geografis. Kesulitan tersebut dikarenakan siswa sulit memahami atau tidak hafal perkalian, siswa kurang memperhatikan saat guru mejelaskan. Mata pelajaran IPS merupakan mata pelajaran yang memerlukan pemahaman lebih. Pemahaman yang lebih dibutuhkan untuk mengrtahui materi pembelajaran IPS yang disajikan dalam setiap buku pedoman siswa. Penyampaian materi yang sama berupa teks bacaan saja sehingga mengakibatkan peserta didik bosan. Siswa yang menghadapi kebosanan melalaikan penjelasan dari guru dan menjalankan kegiatan di luar pembelajaran, contohnya berbicara atau bermain dengan pesert didik lain. Dengan demikian, konsep IPS yang disajikan guru tidak cukup sehingga pemahaman peserta didik kurang.

Berdasarkan pembahasan uraian pembahasan tersebut maka dapat dipaparkan implikasi praktis yakni guru dapat menggunakan langkah perbaikan pembelajaran sebagai upaya menambah profesionalisme kerja. Bagi siswa, implikasi dari penelitian ini adalah menumbuhkan motivasi dan perhatian siswa untuk belajar, meningkatkan pemahaman siswa dalam mata pelajaran IPS, serta membantu meningkatkan minat belajar siswa.

\section{Kesimpulan}

Berdasarkan uraian yang telah dikemukakan pada bab sebelumnya, maka ditarik kesimpulan sebagai berikut: 
Berdasarkan hasil penelitian yang telah dilakukan, peneliti telah mengidentifikasi kendala apa saja yang dialami siswa, dan faktor apa saja yang dapat memengaruhi rendahnya pemaham belajar siswa dalam pembelajaran IPS pada kelas V SDN Mlajah 1.

\section{Ucapan Terimakasih}

Saya Anni farika sebagai penulis mengucapkan terima kasih kepada Allah SWT yang telah memberikan rahmat dan nikmat. Ucapan terima kasih penulis tujukan kepada semua pihak yang telah membantu dalam proses penelitian. Terutama kepada orang tua yang selalu memberikan dorongan berupa semangat dan doa, kepada bapak Agung Setyawan dan ibu Tyasmiarni Citrawati selaku dosen pembimbing penulis, dan terima kasih kepada sekolah serta jajaran guru di SD Negeri Mlajah 1 Bangkalan yang telah memberikan kesempatan untuk melakukan penelitian.

\section{Daftar Pustaka}

Aliyah, Jannatin. Dkk. (2015). Model Pembelajaran Kooperatif Tipe Stad Untuk Meningkatkan Pemahaman Konsep Siswa Pada Materi Cahaya.Ejournal UNESA (hlm.2)

Anderson, L. W., \& Krathwohl, D. R. (2015). Kerangka Landasan Untuk Pembelajaran, Pengajaran, dan Asesmen: Revisi Taksonomi Bloom.Yogyakarta: Pustaka Pelajar.

Hamalik, Oemar. (2013). Kurikulum dan Pembelajaran. Jakarta: Bumi Aksara

Isjoni. (2011). Cooperative Learning Efektivitas Pembelajaran Kelompok. Bandung: Alfabeta

Kesuma, D., Triatna, C, Permana, J. (2011). Pendidikan Karakter: Kajian Teori Dan Praktik Di

Sekolah. Bandung: PT Remaja Rosdakarya.

Permendiknas No.24 tahun 2006. Tentang Ilmu Pengetahuan Sosial (IPS). Jakarta: Depdiknas.

Purwanto,N. (2008). Prinsip-Prinsip Dan Teknik Evaluasi Pengajaran. Bandung:Rosdakarya.

Sapriya. 2009. Pendidikan IPS. Bandung: Remaja Rosdakarya.

Sardiman. 2011. Interaksi \& Motivasi Belajar Mengajar. Jakarta: Rajawali Pers.

Setianingsih, D., Ramadhan, A., \& Gagaramusu, Y. (2014). Meningkatkan Pemahaman Konsep Bagian-Bagian Tumbuhan Melalui Pembelajaran Kooperatif Model Stad Pada Siswa Kelas IV SDN 02 Laantula Jaya Kec. Wita Ponda Kab. Morowali. Jurnal Kreatif Tadulako Online, 3(2), 41-52.

Setianingsih, Dewilis. Dkk. (2014). Meningkatkan Pemahaman Konsep Bagian-Bagian Tumbuhan Melalui Pembelajaran Kooperatif Model Stad Pada Siswa Kelas IV SDN 02 Laantula Jaya Kec.

Wita Ponda Kab. Morowali. Jurnal Kreatif Tadulako Online Vol. 3 No. 2 (Hlm.42)

Slameto. 2010. Belajar dan Faktor yang mempengaruhinya. Jakarta: Rineka Cipta.

Slavin, Robert E. 2009. Cooperative Learning. Bandung: Nusa Media.

Susanto, Ahmad. (2014). Pengembangan Pembelajaran Ips di Sekolah Dasar. Jakarta: Prenadamedia Group. Rusman. (2016). Model-model Pembelajaran Mengembangkan Profesionalisme Guru. Depok: PT Rajagrafindo Persada 